\title{
Central Nevada riparian areas: Physical and chemical properties of meadow soils
}

\author{
JEANNE C. CHAMBERS, ROBERT R. BLANK, DESIDERIO C. ZAMUDIO, AND ROBIN J. TAUSCH
}

Authors are research ecologist, USDA Forest Service, Rocky Mountain Research Station, Reno, Nev. 89512; soil scientist, USDA Agricultural Research Service, Reno, Nev. 89512; soil scientist, USDA Forest Service, Humboldt-Toiyabe National Forest, Sparks, Nev. 89431; and range scientist, USDA Forest Service, Rocky Mountain Research Station, Reno, Nev. 89512.

\section{Abstract}

Despite the importance of soil characteristics for classifying riparian ecosystem types and evaluating ecosystem or range condition, little information exists on western riparian area soils or the factors that influence them. We examined the effects of drainage basin geology and water table depth on soil morphology and soil physical and chemical properties of meadow sites in central Nevada. We described and analyzed the soils of meadows that occurred in $\mathbf{4}$ drainages with different geology and that exhibited high water tables $(0$ to $-20 \mathrm{~cm}$ from the surface), intermediate water tables $(-30$ to $-50 \mathrm{~cm})$, and low water tables $(-60$ to $-80 \mathrm{~cm})$. Pedons of high water tables sites had thick $\mathrm{O}_{\mathrm{e}}$ horizons, dark, fine-textured $\mathrm{A}$ horizons, no $B$ horizons, and lower $\mathrm{C}$ horizons high in coarse fragments. In contrast, pedons of low water tables sites were characterized by deep, dark and organic-rich A horizons, cambic $B$ horizons, and deep rooting profiles. High water tables sites had higher organic matter, total nitrogen, cation exchange capacity, and extractable potassium, but lower $\mathrm{pH}$ than low water table sites. Also, high water table sites had lower percentage sand, lower bulk densities, and higher soil moisture retention. The importance of organic matter was evidenced by strong positive product moment correlations for organic matter and total nitrogen, cation exchange capacity, and extractable potassium. Significant differences in $\mathbf{p H}$, extractable potassium and extractable phosphorus existed among drainages that were explainable largely from the parent materials. Drainages with chert, quartzite, and limestone had higher silt and clay, neutral pH, and high levels of extractable phosphorus. Drainages formed in acidic volcanic tuffs, rhyolites and breccia were characterized by coarser textured soils and low pH and extractable phosphorus. In riparian areas, soil water table depth interacts with soil parent material to significantly affect soil morphology and soil physical and chemical properties. Because these factors vary over both large and small spatial scales, differences among sites must be carefully interpreted when classifying ecosystems or evaluating ecosystem condition.

Key Words: water tables, watershed geology, soil morphology, soil quality, ecosystem classification, ecosystem condition

The authors thank Michael C. Amacher for manuscript review. The use of trade or firm names in this paper is for reader information and does not imply endorsement by the USDA of any product or service.

Manuscipt accepted 10 Apr. 1998

\section{Resumen}

A pesar de la importancia de las catacteríticas de los suelos para clasificar los tipos de ecosistemas ribereños y evaluar la condición de ecosistemas y pastizales existe poca información sobre los suelos del rea ribereña el oeste y los factores que los afectan. Examinamos el efecto de la geología del drenaje de la cuenca y la profundidad del manto freático en la morfología y propiedades fisico-químicas de los suelos de vega en la región central de Nevada. Describimos y analizamos los suelos de vega que ocurren en 4 dernajes con diferente geología y que tienen mantos freáticos alto $(0 \mathrm{a}-20 \mathrm{~cm}$ de la superficie ), intermedio $(-30$ a $-50 \mathrm{~cm})$ y bajo $(-60$ a $-80 \mathrm{~cm})$. Los pedones de sitios con manto freático alto tuvieron horizontes $O_{c}$ anchos, horizontes A obscuros y de textura fina, sin horizontes $B$ y los horizontes $C$ bajos con alto contenido de fragmentos gruesos. En contraste, los pedones de los sitios con manto freático bajo se caracterizaron por tener horizontes $\mathrm{A}$ profundos, obscuros y ricos en material orgánico, horizontes B cambicos y perfiles de enraizamiento profundos. Los sitios de manto freático alto tuvieron altos contenidos de materia orgánica, nitrógeno total, potasio extractable, alta capacidad de intercambio cationico y $\mathbf{p H}$ menor que los sitios con mantos freáticos bajos. Los sitio con manto freático también tuvieron un menor porcentaje de arena, menor densidad aparente y mayor retención de humedad del suelo. La importancia de la materia orgánica se evidenció or fuertes correlaciones positivas momento producto entre materia orgánicay nitrógeno total, capacidad de intercambio cationico y potasio extractable. Existieron diferencias significativa entre drenajes respecto a $\mathrm{pH}$, potasio y fósforo extractables las cuales se explican en gran parte por el material parental. Drenajes con "Chert", cuarcita y piedra caliza tuvieron mas limo y arcilla, pH neutro y valores altos de fósforo extractable. Drenajes formados en tufas, riolitas y brechas volcánico ácidos se caracterizaron por suelos de textura gruesa, bajo $\mathrm{pH}$ y bajo contenido de fósforo extractable. En áreas ribereñas la profundidad del manto freático interactua con el material parental del suelo para afectar significativamente la morfología del suelo y sus propiedades físico- químicas. Debido a que estos factores varian en escales espaciales grandes y pequeñas, las diferencias entre sitos deben ser interpretadas cuidadosamente para clasificar los ecosistemas o evaluar la condición del ecosistema 
Information on soil characteristics is essential for understanding riparian ecosystem patterns on the landscape and for assessing the effects of various land management activities on those ecosystems (Malanson 1993). Soil properties are commonly used to classify and delineate riparian ecosystem types (e.g., Hansen 1992, Weixelman et al. 1997). They are equally important for evaluating ecosystem or range condition (Wilson and Tupper 1982), although they are less frequently used for that purpose. Soil characteristics used to classify riparian ecosystems serve as indicators of the influence of regional factors such as climatic regime, geomorphic position, and hydrology on soil development, and for riparian ecosystems usually include soil type from pedon descriptions, depth to water table or saturation, and soil texture. In contrast, soil characteristics used to evaluate ecosystem condition serve as indicators of the combined influences of human-caused and natural disturbance on soil physical and chemical properties and biotic processes within ecosystem types (e.g., Breckenridge et al. 1995). Although soil characteristics for evaluating rangeland ecosystem conditions have not been standardized, measures of soil "quality" have been developed for agronomic situations that include measures of soil physical and chemical properties and biotic processes (Doran and Parkin 1994, 1996). When combined with the soil variables used to classify ecosystem types, these measures appear to be appropriate for detailed assessments of rangeland ecosystem condition (Harris et al. 1996).

Effectively using measures of soil characteristics to either classify riparian ecosystems or to assess ecosystem condition requires knowledge of the natural variability of the soils within these ecosystems. In riparian ecosystems, both drainage basin geology and depth to water table significantly influence soil characteristics. The geologic composition of watersheds influences physical soil characteristics such as coarse fragments and soil texture, and chemical characteristics such as $\mathrm{pH}$ and available phosphorus and potassium. Because of its effect on the depth to soil saturation and, thus, mineralization processes, water table depth influences soil properties such as organic matter, total nitrogen, cation exchange capacity, and $\mathrm{pH}$ (Mitsch and Gosselink 1993). In this study, we evaluated the degree of variability in central Nevada meadow ecosystem soils using several physical and chemical measures of soil "quality." The objectives were (1) to examine the relative influence of both watershed geology and water table on the physical and chemical soil properties of wet and mesic meadow ecosystems; and (2) to evaluate the implications of the results for classifying riparian ecosystems and for assessing ecosystem condition. This research was conducted as part of a USDA Forest Service ecosystem management project that is seeking to obtain a better understanding of the structure of central Nevada riparian ecosystems and to develop management guidelines for maintaining or restoring riparian ecosystem integrity (Chambers 1994).

\section{Materials and Methods}

\section{Study Area}

The study area is in the Toiyabe Mountain Range in central Nevada. Watershed elevations range from about 1,850 to $3,200 \mathrm{~m}$. Precipitation ranges from $20 \mathrm{~cm}$ at the bases of the watersheds to $45 \mathrm{~cm}$ at the upper elevations with approximately $60 \%$ of the precipitation arriving as winter snow. Peak runoff is during snowmelt in early June, but convective summer storms also result in significant runoff and erosion. Valley floors are often characterized by salt desert vegetation, including shadscale (Atriplex confertifolia [Torr. \& Frem.] Watts) and winterfat (Ceratoides lanata [Pursh.] J. Howell). At low to middle elevations, Wyoming big sagebrush (Artemisia tridentata spp. wyomingensis Beetle \& A. Young) communities are interspersed with Utah juniper (Juniperous osteosperma [Torrey] Little) and single leaf pinyon (Pinus monophylla Torrey \& Fremont) woodlands. At higher elevations, mountain big sage- brush (Artemisia tridentata spp. vaseyana Beetle) and limber pine (Pinus flexilis James) dominate. Riparian vegetation consists of stringers of quaking aspen (Populus tremuloides Michaux), narrow leaf cottonwood (Populus angustifolia James), river birch (Betula occidentalis Hook), willows (Salix spp.), and meadow communities. These ecosystems have been grazed by livestock since European settlers colonized the area.

The stream systems are typically located within confined valleys, exhibit high gradients, and are incised (USDA Forest Service 1996). Low flows in these stream systems range from about $0.0057 \mathrm{~m}^{3} \mathrm{sec}^{-1}$ to 0.0567 $\mathrm{m}^{3} \mathrm{sec}^{-1}$ (Hess and Bohman 1996). Meadow systems are associated with hillslope springs or seeps, or crossvalley alluvial fans or other nick points that block down-valley subsurface flows and result in locally higher water tables. Stream incision tends to be highest above the alluvial fans and meadow systems, but downcutting within the meadows can result in lowered water tables.

This study focuses on 4 drainages with varying geology-Kingston Canyon, Big Creek, Washington Creek, and San Juan Creek. The Toiyabe mountains are a typical northsouth fault-blocked range with complex structural geology (Kleinhample and Ziony 1985). Bedrock geology of Kingston Canyon is dominated by Ordovician chert with minor greenstone, pillow lavas and shale with some areas influenced by deposition of Devonian-Silurian silty limestone. Bedrock geology of Big Creek is mostly Ordovician chert containing minor greenstone, pillow lavas and Ordovician-Cambrian phyllites and slate with laminated limestone. Washington Creek is dominated by Proterozoic quartzite with minor Ordovician shale and limestone, some locally metamorphosed to slate and marble. The San Juan watershed is dominated by a Tertiary rhyolitic to rhyo-dacitic welded ash flow tuff unit that is locally brecciated and somewhat argillized. 


\section{Field Methods}

Within the 4 drainages, meadow sites were selected with perennially high water tables ( 0 to $-20 \mathrm{~cm}$ from the surface), intermediate water tables $(-30$ to $-50 \mathrm{~cm})$, or low water tables $(-60$ to $-80 \mathrm{~cm})$. The study sites range from 2,180 to 2,330 m. Meadows with high water tables correspond to the Nebraska sedge ecosystem type and are dominated by Nebraska sedge (Carex nebrascensis Dewey), while those with low water tables are classified as the mesic graminiod ecosystem type and are dominated by Kentucky bluegrass (Poa pratensis L.) (USDA Forest Service 1996). Those with intermediate water tables are characterized by both Nebraska sedge and Kentucky bluegrass. In Kingston Canyon and Big Creek, only meadows with low and high water tables could be located for sampling, while in Washington Creek and San Juan Creek meadows with low, intermediate, and high water tables were located and sampled.

Soil pedons from each of the 10 meadow sites were described using standard methods (Soil Survey Staff 1984). Also, 4 replicate soil samples were collected from each of the meadow sites in August, 1994. Each sample was randomly located and consisted of a composite of 3 cores $(10 \mathrm{~cm}$ diam.) taken $0.5 \mathrm{~m}$ apart. Samples were stratified by depth and were collected from the $0-5,10-20$, and $30-40 \mathrm{~cm}$ depths. In addition, 4 replicate bulk density measurements were made in the field on each meadow site using the rubberballoon excavation method (Blake and Hartge 1986) and excavated holes of approximately $400 \mathrm{~cm}^{2}$ surface-area and $15 \mathrm{~cm}$ depth. Depth to water table has been monitored from $3,10 \mathrm{~cm}$ diam. wells (perforated PVC pipe) for each of the meadow sites in August of 1994, 1996, and 1997.

\section{Laboratory Methods}

Chemical and physical soil analyses of the $<2 \mathrm{~mm}$ fraction were conducted by the Soil, Plant, and Water Analysis Laboratory at Utah State University. All samples were analyzed for organic matter, total nitrogen, $\mathrm{pH}$, extractable phosphorus, extractable potassium, and texture. In addition, samples from the Washington Creek meadows were analyzed for extractable cations, cation exchange capacity, and moisture retention. Total organic matter was determined by ashing (Storer 1984, Schulte 1988) and total nitrogen was evaluated with a modified micro-Kjeldahl digestion procedure (Bremner and Mulvaney 1982). A 1:1 ratio of soil: $\mathrm{H}_{2} \mathrm{O}$ was used to determine $\mathrm{pH}$ (McLean 1982), and cation exchange capacity and extractable cations were evaluated using $1 \mathrm{~N} \mathrm{NH}_{4} \mathrm{OAc}$ at $\mathrm{pH} 7$ (Thomas 1982). Phosphorus was extracted using $\mathrm{NaHCO}_{3}$ (Olsen and Sommers 1982). Percentage coarse fragments (> 2-mm) were determined by sieving. Particledistribution of the $<2-\mathrm{mm}$ fraction was determined by the hydrometer method (Gee and Bauder 1982). Soil water retention was determined using the pressure plate method at $0.03 \mathrm{MPa}$ and 1.5 MPa (Klute 1982).

\section{Statistical Analyses}

Repeated-measures analyses of variance (ANOVA) were used to examine differences among drainages, soil water tables, and depths with depth as the repeated factor (Statistical Analysis
System 1990). One analysis evaluated differences among all 4 drainages for the high and low soil water tables; a second examined differences among all 3 water tables for Washington and San Juan Creeks. For the soils data collected from the Washington Creek sites, the comparisons evaluated differences among water tables and depths. Mean comparisons were performed using Fisher's Protected LSDs (Steel and Torrie 1980). Product moment correlations were used to evaluate relationships among the different soil variables.

\section{Results}

Differences in soil profile characteristics among the 3 water table depth classes are summarized in Table 1 . Pedons from meadows with high water tables are characterized by thick $\mathrm{O}_{\mathrm{e}}$ horizons, dark, relatively fine-textured and organic-rich A horizons, and lower $\mathrm{C}$ horizons with higher coarsefragment contents. Profile differentiation, as in the formation of B horizons is absent. Because of the high water table, gleyed soil matrix colors begin at $16 \mathrm{~cm}$. In general, pedons with both

\begin{tabular}{|c|c|c|c|c|c|}
\hline \multicolumn{6}{|c|}{$\begin{array}{l}\text { Table 1. Pedon descriptions representative of low }(-60 \text { to }-80 \mathrm{~cm}) \text {, intermediate }(-30 \text { to }-50 \mathrm{~cm}) \text {, } \\
\text { and high }(0 \text { to }-20 \mathrm{~cm}) \text { water table depths. }\end{array}$} \\
\hline \multicolumn{2}{|c|}{ Horizon } & $\begin{array}{l}\text { Munsell } \\
\text { Depth moist } \\
\text { color } \\
\end{array}$ & Texture & \multirow[t]{2}{*}{$\mathrm{pH}$} & \multirow[t]{2}{*}{$\begin{array}{c}\text { Root } \\
\text { abundance }\end{array}$} \\
\hline \multicolumn{4}{|c|}{ Low water table - Aquic Cryoboroll } & & \\
\hline & $(\mathrm{cm})$ & & & & \\
\hline A & $0-10$ & 10YR 2/1 & silt loam & 6.6 & many \\
\hline Bw1 & $10-23$ & 10YR 2/1 & silt loam & 6.6 & common \\
\hline Bw2 & $23-45$ & 10YR 2/1 & silt loam & 6.6 & common \\
\hline Bw3 & $45-79$ & 10YR 3/1 & silt loam & 6.6 & common \\
\hline $\mathrm{Cg} 1$ & 79-104 & 10YR 3/1 & loam & 6.8 & few \\
\hline $\mathrm{Cg} 2$ & $104-120$ & $10 \mathrm{YR} 3 / 1$ & sandy clay loam & 6.8 & absent \\
\hline \multicolumn{6}{|c|}{ Intermediate water table - Cumulic Cryaquoll } \\
\hline A1 & $0-11$ & $10 \mathrm{YR} 2 / 2$ & silt loam & 6.8 & many \\
\hline A 2 & $11-32$ & 7.5YR 2.5/1 & sandy loam & 6.6 & common \\
\hline $\mathrm{Ag}$ & $32-53$ & 7.5YR 2.5/1 & gravelly sandy loam & 6.8 & common \\
\hline $2 \mathrm{C}$ & $53-115$ & 10YR 3/1 & v. gravelly sandy loam & 7.0 & few \\
\hline & $2 \mathrm{Cg}$ & $115-1235 \mathrm{GY} 5 / 1$ & v. gravelly sandy loam & 7.2 & few \\
\hline \multicolumn{6}{|c|}{ High water table - Typic Cryaquoll } \\
\hline Oe & $0-16$ & $10 \mathrm{YR} 2 / 2$ & fibric & 6.2 & many \\
\hline $\mathrm{Ag}$ & $16-29$ & 10YR 2/1 & loam & 6.2 & many \\
\hline A & $29-54$ & 10YR 2/1 & gravelly sandy loam & 6.4 & common \\
\hline $2 \mathrm{C}$ & $54-93$ & 10YR 3/1 & gravelly sandy loam & 6.6 & common \\
\hline $2 \mathrm{Cg}$ & 93- & $5 \mathrm{GY} 4 / 1$ & v. gravelly sandy loam & 7.0 & few \\
\hline
\end{tabular}




\begin{tabular}{|c|c|c|c|}
\hline \multicolumn{4}{|c|}{$\begin{array}{l}\text { Table } 2 \text {. August depth to water table for sites } \\
\text { categorized as having low, intermediate, } \\
\text { and high water tables in the study } \\
\text { drainages. Values are mean } \pm \text { S.E.; } n=3 \text {. }\end{array}$} \\
\hline & \multicolumn{3}{|c|}{ Depth to water table } \\
\hline $\begin{array}{l}\text { Study } \\
\text { drainage }\end{array}$ & 1994 & 1996 & 1997 \\
\hline & $-(\mathrm{c} r)$ & m) & - \\
\hline $\begin{array}{l}\text { Kingston } \\
\text { Big Creek } \\
\text { Washington } \\
\text { San Juan }\end{array}$ & $\begin{array}{l}67 \pm 0 * \\
70 \pm 0 \\
50 \pm 0 \\
63 \pm 0\end{array}$ & $\begin{array}{l}88 \pm 5 \\
77 \pm 3 \\
40 \pm 7 \\
84 \pm 8\end{array}$ & $\begin{array}{l}82 \pm 6 \\
77 \pm 3 \\
56 \pm 11 \\
83 \pm 10\end{array}$ \\
\hline $\begin{array}{l}\text { Intermediate } \\
\text { Washington } \\
\text { San Juan }\end{array}$ & $\begin{array}{l}30 \pm 0 \\
54 \pm 0\end{array}$ & $\begin{array}{l}20 \pm 2 \\
72 \pm 12\end{array}$ & $\begin{array}{l}29 \pm 3 \\
70 \pm 17\end{array}$ \\
\hline $\begin{array}{l}\text { High } \\
\text { Kingston } \\
\text { Big Creek } \\
\text { Washington } \\
\text { San Juan }\end{array}$ & $\begin{aligned} 5 & \pm 0 \\
0 & \pm 0 \\
0 & \pm 0 \\
20 & \pm 0\end{aligned}$ & $\begin{aligned} 18 & \pm 2 \\
0 & \pm 0 \\
0 & \pm 0 \\
-- & \end{aligned}$ & $\begin{aligned} & 20 \pm 0 \\
& 2 \pm 0 \\
& 2 \pm 0 \\
&--\end{aligned}$ \\
\hline
\end{tabular}

low and intermediate water tables lack O horizons. Pedons with intermediate water tables are characterized by thick dark organic-rich mineral A horizons that grade into $\mathrm{C}$ horizons with low organic-content and increasing coarsefragment content. These pedons also show little evidence of profile differentiation. Pedons with low water tables are characterized by deep, dark and organic-rich profiles and the expression of cambic $\mathrm{Bw}$ horizons. All of the meadow types were characterized by abundant roots to depths of $50 \mathrm{~cm}$ or deeper.

Depths to the water table in August of 1994, 1996, and 1997 varied among sites, but most values are within the expected ranges based on initial surveys for the different soil water categories (Table 2). A potential outlier based on depth to water table is the Washington Creek site within the low soil water category.

Percentage coarse fragments in the soil are highly variable both among and within watersheds resulting in no statistical differences among water tables, sites, or depths (Fig. 1). Percentage sand is lower on the high water table sites than on the low or intermediate water table sites, and the highest percentages of silt and clay occurs on the low water table sites. The Kingston Canyon sites have significantly higher clay and silt and

\begin{tabular}{|c|c|c|c|}
\hline \multirow[b]{2}{*}{ Drainage } & \multicolumn{3}{|c|}{ "Bulk density } \\
\hline & $\begin{array}{c}\text { Low } \\
\text { water table }\end{array}$ & $\begin{array}{l}\text { Intermediate } \\
\text { water table }\end{array}$ & $\begin{array}{c}\text { High } \\
\text { water table }\end{array}$ \\
\hline & 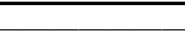 & $\left(\mathrm{Mg} / \mathrm{m}^{3}\right)$ & - \\
\hline Kingston & $0.50 \pm 0.40 \mathrm{a} \mathrm{A}$ & - & $0.26 \pm 0.01 \mathrm{a} \mathrm{B}$ \\
\hline Big Creek & $0.55 \pm 0.06 \mathrm{a} A$ & - & $0.11 \pm 0.02 b \mathrm{~B}$ \\
\hline Washington & $0.35 \pm 0.03 \mathrm{~b} \mathrm{~A}$ & $0.43 \pm 0.02 \mathrm{a} \mathrm{A}$ & $0.14 \pm 0.02 b \mathrm{~B}$ \\
\hline San Juan & $0.47 \pm 0.05 \mathrm{a} \mathrm{A}$ & $0.40 \pm 0.07 \mathrm{a} \mathrm{A}$ & $0.16 \pm 0.04 \mathrm{~b} \mathrm{~B}$ \\
\hline
\end{tabular}

lower sand than the other sites for both the low and high water tables, potentially explaining some of the overall statistical differences in soil texture among water levels.

Bulk density of the $0-15 \mathrm{~cm}$ depth and soil moisture retention differ significantly among soil water tables. Bulk densities for high water table sites are consistently lower than for either low or intermediate water table sites, but there are no differences in bulk densities between low and intermediate water table sites (Table 3). Within water table categories, the Washington Creek site has lower bulk densities than the other low water table sites, while the Kingston Canyon site has higher bulk densities than the other high water table sites. For the Washington Creek meadows, soil moisture retention is higher on the high water table site than on the low or intermediate water table sites at both $0.03 \mathrm{MPa}$ and $1.5 \mathrm{MPa}$ (Table 4). Moisture retention tends to decrease with depth.

Both soil organic matter and total Kjeldahl nitrogen are highest on high water table sites and do not differ between low and intermediate water table sites (Fig. 2). Differences among sites exist and the San Juan site has lower organic matter and total nitrogen than the other low water table sites, while the Washington Creek site

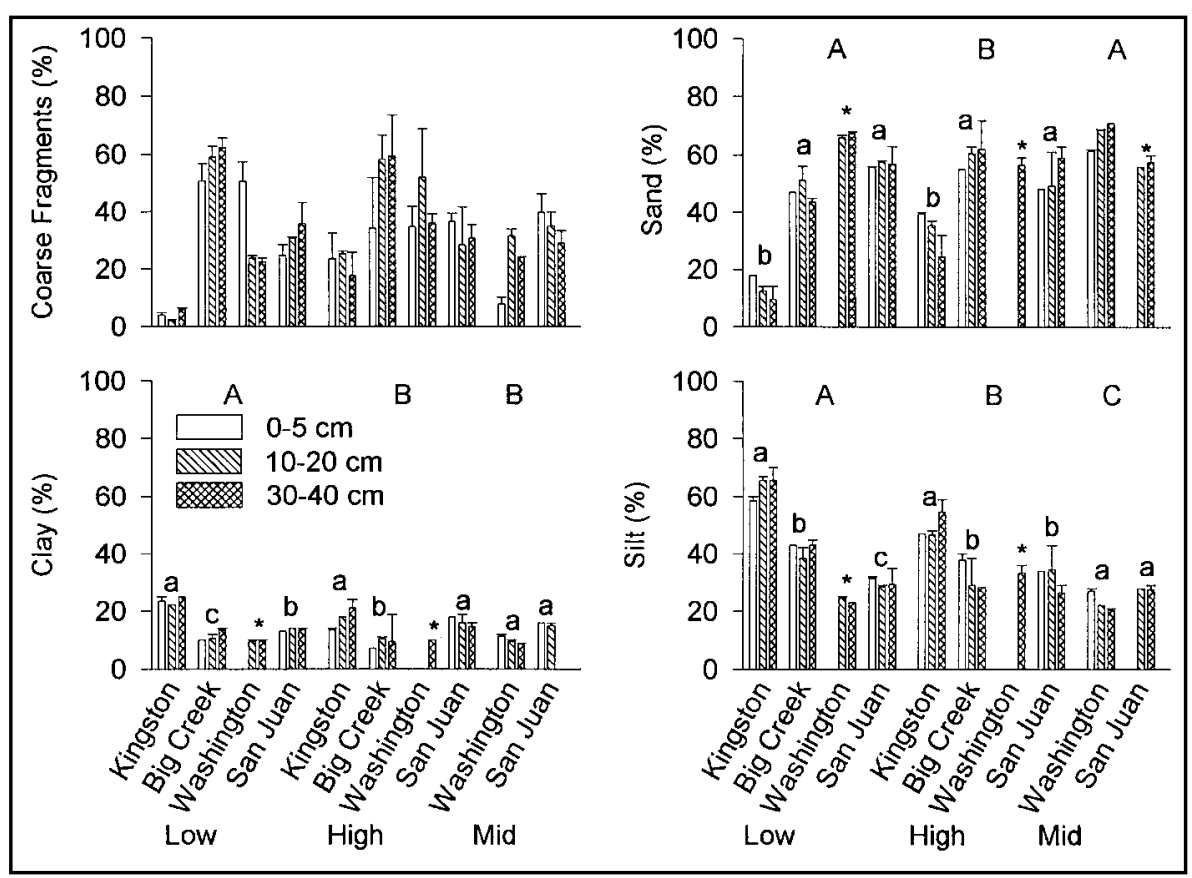

Fig. 1. Soil physical properties for low, high, and intermediate (mid) water tables for meadow sites within the 4 study drainages. Upper case letters indicate significant differences among water tables; lower case letters indicate differences among drainages within a soil water table category (Fisher's LSD, $P<0.05$ ). 


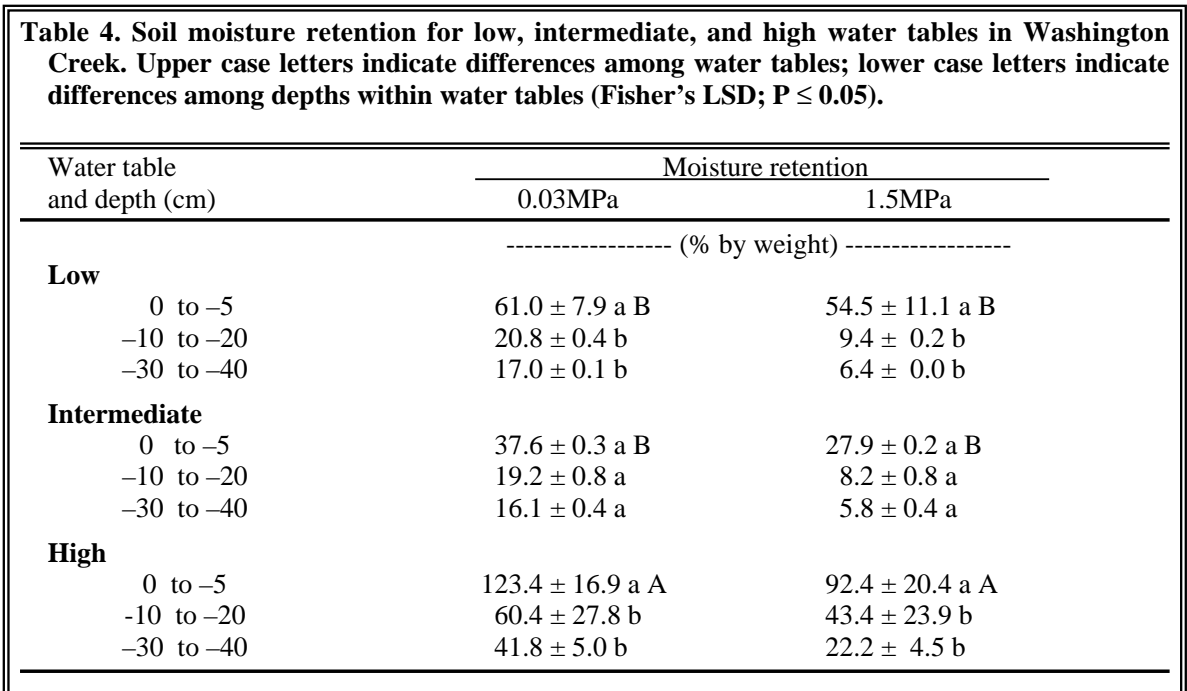

has higher organic matter and total nitrogen than the other high water table sites. Both organic matter and total nitrogen decrease significantly with depth $(\mathrm{P}<0.001)$. The $\mathrm{pH}$ decreases with increasing water table level (Fig. 2). Significant differences exist among sites within water table levels with the San Juan sites having consistently lower $\mathrm{pH}$ values. Overall, $\mathrm{pH}$ decreases significantly with depth $(\mathrm{P}<.01)$. Extractable phosphorus levels are significantly higher on low water table sites than on either high or intermediate water table sites (Fig. 2). This is primarily because of the high levels of extractable phosphorus for the Kingston Canyon site within the low water table category. Within the high water table category, the Kingston Canyon site also exhibits higher levels of extractable phosphorus than the other sites. In contrast to extractable phosphorus, the high water table sites have higher levels of extractable potassium than the low water table sites. However, this again appears to be attributable to the high values for a single site-Washington Creek. Within water table categories, the San Juan sites have higher levels of extractable potassium than other sites for both the low and intermediate water tables. Levels of extractable potassium decline with depth across water table categories and sites $(\mathrm{P}<0.001)$.

Cation exchange capacities measured for the Washington Creek meadow sites are higher on the high water table site than on the low or intermedi- table categories.

Pearson product-moment correlations for the major soil properties are in Table 6. Negative correlations existed between $\mathrm{pH}$, cation exchange capacity and potassium. However, $\mathrm{pH}$ was positively correlated with bulk density. As expected, levels of organic matter and total nitrogen were highly correlated among sites. Positive correlations existed for organic matter, total nitrogen, cation exchange capacity, potassium, and soil water retention. Organic matter, cation exchange capacity, and extractable potassium were negatively correlated with sand, but positively correlated with silt.

\section{Discussion}

3 water table categories, cation exchange capacity declined significantly with depth. Individual exchangeable cations did not differ among water table categories, but decreased with depth within water

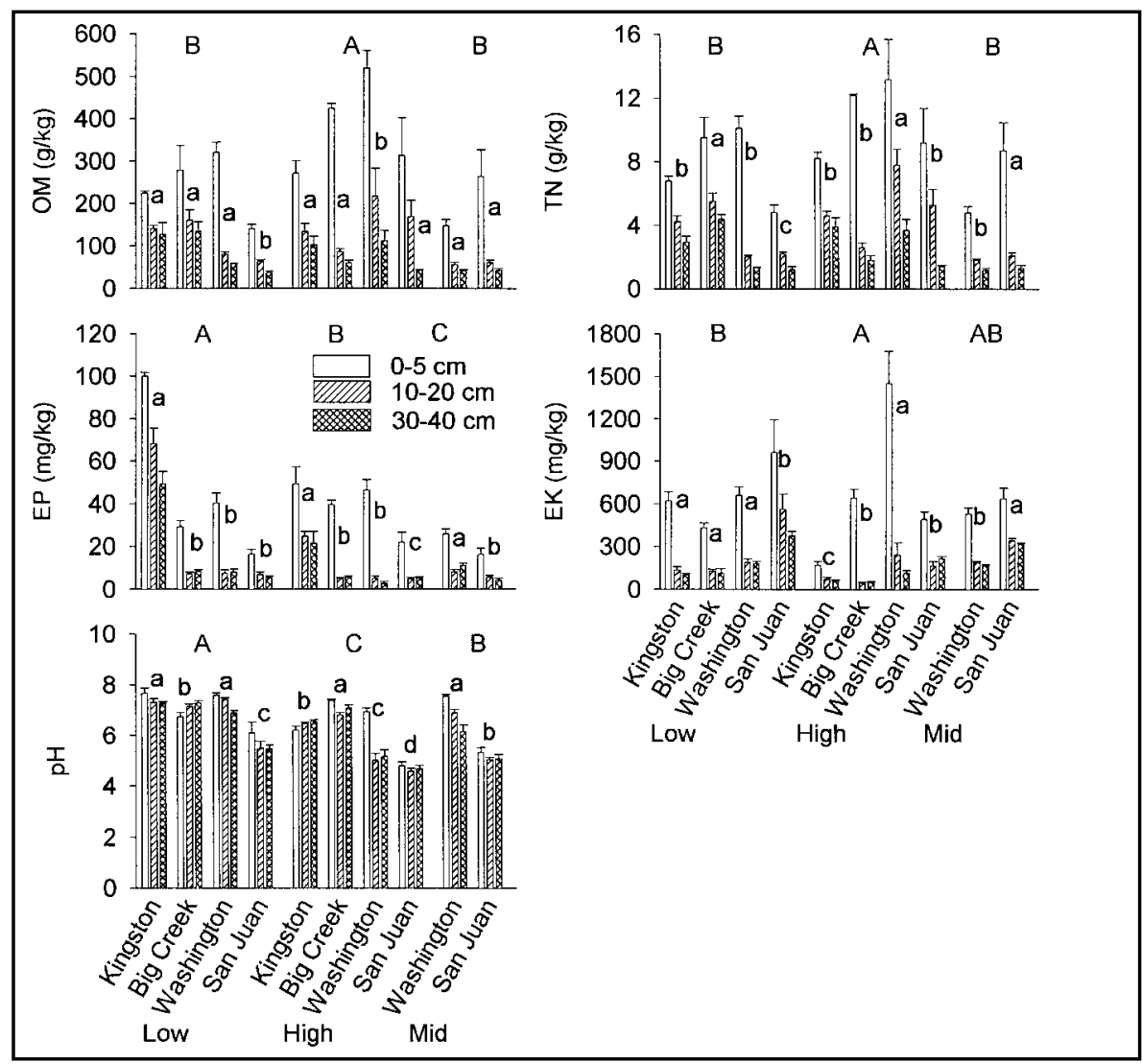

Fig. 2. Soil chemical properties for low, high, and intermediate (mid) water tables for meadow sites within the 4 study drainages. Upper case letters indicate significant differences among water tables; lower case letters indicate differences among drainages within a soil water table category (Fisher's LSD, $P<0.05$ ). 


\begin{tabular}{|c|c|c|c|c|c|}
\hline \multicolumn{6}{|c|}{$\begin{array}{l}\text { Table 5. Cation exchange capacities and exchangeable cations for low, intermediate, and high } \\
\text { water tables in Washington Creek. Upper case letters indicate differences among water table } \\
\text { levels; lower case letters indicate differences among depths within water tables (Fisher's LSD; } \\
P \leq \mathbf{0 . 0 5} \text { ). }\end{array}$} \\
\hline \multirow{2}{*}{$\begin{array}{l}\text { Water table } \\
\text { and depth }\end{array}$} & \multirow{2}{*}{$\begin{array}{l}\text { Cation-exchange } \\
\text { capacity }\end{array}$} & \multicolumn{4}{|c|}{ Exchangeable cations } \\
\hline & & $\mathrm{Ca}$ & $\mathrm{Mg}$ & K & $\mathrm{Na}$ \\
\hline$(\mathrm{cm})$ & $(\mathrm{cmol} / \mathrm{kg})$ & & $-(\mathrm{cm}$ & 1) & \\
\hline \multicolumn{6}{|l|}{$\begin{array}{l}\text { (cm) } \\
\text { Low }\end{array}$} \\
\hline 0 to -5 & $49.9 \pm 6.6 \mathrm{a} \mathrm{B}$ & $42.8 \pm 1.7 \mathrm{a}$ & $4.7 \pm 0.3 \mathrm{a}$ & $0.8 \pm 0.1 \mathrm{a}$ & $0.03 \pm 0.08$ \\
\hline-10 to -20 & $21.5 \pm 0.7 b$ & $14.4 \pm 0.4 b$ & $0.9 \pm 0.1 b$ & $0.4 \pm 0.1 b$ & $0.03 \pm 0.00$ \\
\hline-30 to -40 & $18.0 \pm 1.0 \mathrm{~b}$ & $8.4 \pm 0.1 b$ & $0.6 \pm 0.1 b$ & $0.3 \pm 0.1 b$ & $0.02 \pm 0.01$ \\
\hline \multicolumn{6}{|l|}{ Intermediate } \\
\hline 0 to -5 & $32.3 \pm 1.4 \mathrm{a} \mathrm{B}$ & $31.2 \pm 2.1 \mathrm{a}$ & $2.9 \pm 0.4 \mathrm{a}$ & $0.8 \pm 0.1 \mathrm{a}$ & $0.01 \pm 0.01$ \\
\hline-10 to -20 & $19.8 \pm 1.2 \mathrm{~b}$ & $10.4 \pm 0.7 \mathrm{~b}$ & $0.8 \pm 0.1 \mathrm{~b}$ & $0.3 \pm 0.1 b$ & $0.02 \pm 0.01$ \\
\hline-30 to -40 & $16.3 \pm 0.9 b$ & $7.1 \pm 0.6 b$ & $0.6 \pm 0.1 b$ & $0.2 \pm 0.1 b$ & $0.02 \pm 0.01$ \\
\hline \multicolumn{6}{|l|}{ High } \\
\hline 0 to -5 & $78.5 \pm 6.3 \mathrm{a} \mathrm{A}$ & $33.6 \pm 8.8 \mathrm{a}$ & $3.2 \pm 0.7 \mathrm{a}$ & $1.0 \pm 0.1 \mathrm{a}$ & $0.14 \pm 0.09$ \\
\hline-10 to -20 & $54.8 \pm 19.0 \mathrm{~b}$ & $18.2 \pm 0.5 b$ & $0.8 \pm 0.4 b$ & $0.2 \pm 0.1 b$ & $0.16 \pm 0.13$ \\
\hline-30 to -40 & $43.8 \pm 7.8 \mathrm{~b}$ & $18.9 \pm 4.0 \mathrm{~b}$ & $1.2 \pm 0.4 \mathrm{~b}$ & $0.2 \pm 0.1 b$ & $0.03 \pm 0.00$ \\
\hline
\end{tabular}

by different water tables or located in different drainages. Soil development and morphological characteristics are strongly influenced by depth to water table. The thickness and organic matter content of surface horizons declines with decreases in average water table depth. This is not unexpected given that mineralization of organic matter decreases with increasing water content in these wet and mesic soils. Only the low water table $(-60$ to $-80 \mathrm{~cm})$, mesic graminiod ty and extractable potassium, but lower $\mathrm{pH}$. Also, sites with lower depth to saturation have lower bulk densities and higher soil moisture retention. Levels of organic matter often increase with decreasing water table depth (e.g., Johnston et al. 1995) due to lower mineralization rates. Soil organic matter content influences many other variables (see Mitsch and Gosselink 1993) which is evident from the product moment correlations for the Washington Creek sites. Strong positive correlations exist for organic matter, total nitrogen, cation exchange capacity and extractable potassium, while a negative correlation exists between organic matter and $\mathrm{pH}$. Higher levels of organic matter result in a greater number of cation exchange sites, and the tendency toward decreasing $\mathrm{pH}$ with higher levels of organic matter is common in meadow ecosystems (Naiman et al. 1994). The high correlation between extractable potassium and organic matter suggests that a large proportion of extractable potassium is associated with the soil organic fraction. This would be unusual because research has shown that the largest pool of extractable potassium is associated

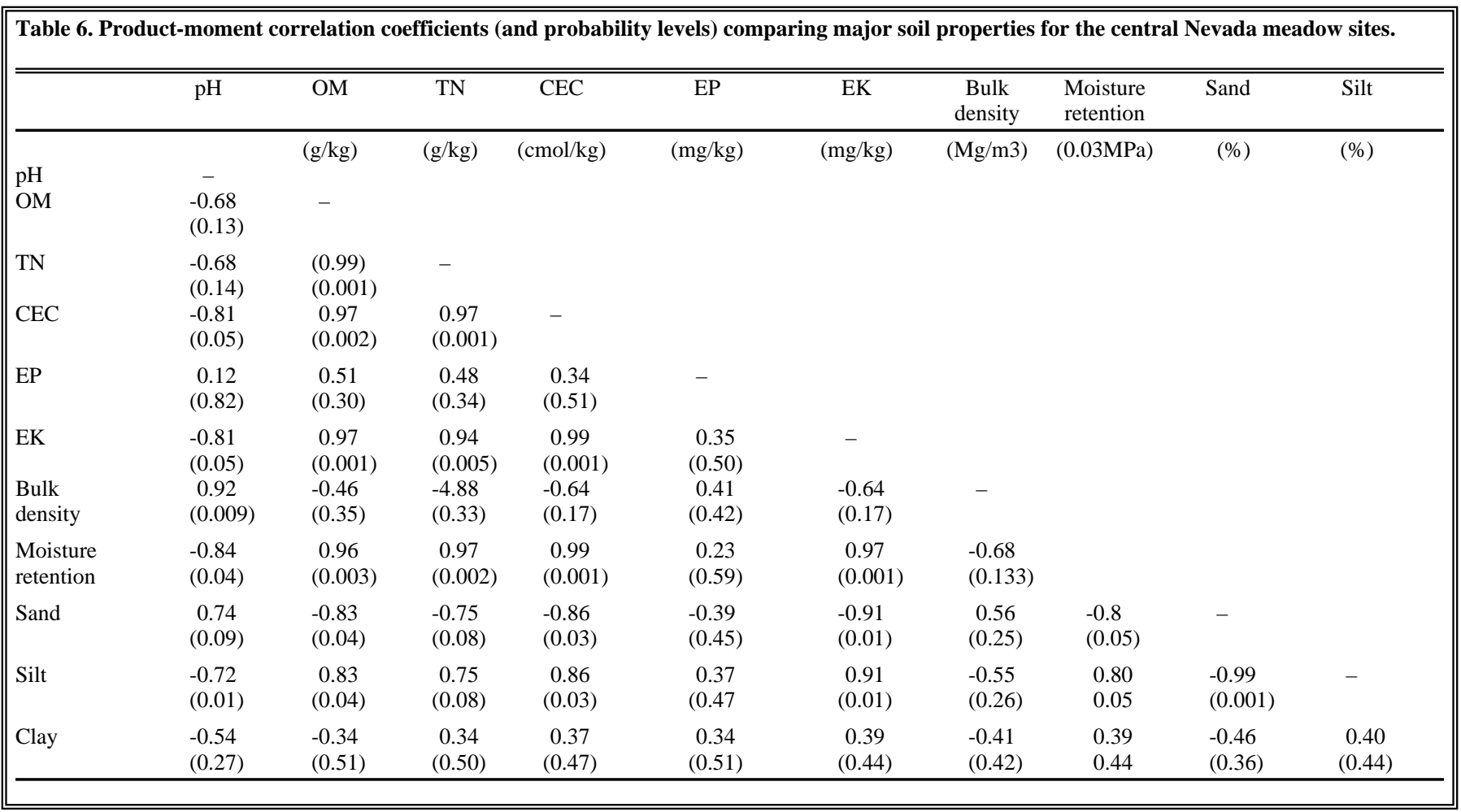


with 2:1 silicate clay minerals such as illite (Lindsay 1979). The high negative correlation between organic matter and soil bulk density is to be expected (Miller et al. 1965). The bulk density values obtained for the $0-15$ $\mathrm{cm}$ depth here are similar to those for O horizons in other meadow soils (Johnston et al. 1995, Naiman et al. 1994) and for organic soils in general (i.e., 0.2 to $0.3 \mathrm{Mg} / \mathrm{m}^{2}$ ) (Brady 1974).

The geological characteristics of the different drainage basins contributed significantly to the variability among sites, influencing soil texture and $\mathrm{pH}$, extractable phosphorus, and extractable potassium. Kingston Canyon is characterized by high percentages of silt and clay, neutral $\mathrm{pH}$, and high levels of extractable phosphorus. Big Creek also has high percentages of silt and neutral $\mathrm{pH}$. These 2 drainages are in close proximity and consist primarily of erosion resistant chert and quartzite with a strong limestone component (Stewart and McKee 1977). While chert and quartzite are resistent to weathering, admixed limestone decomposes primarily to silts and clays resulting in nearly neutral soil $\mathrm{pH}$ values. Higher phosphate levels in Kingston Canyon can be attributed to a high content of $\mathrm{Ca}$ phosphate minerals in the parent materials. In Washington Creek soils are coarser-textured and tend towards lower $\mathrm{pH}$ and extractable phosphorus and extractable potassium levels. This is because quartzite (metamorphozed sandstone) with a minor limestone component is the principal catchment material (Stewart and McKee 1977). San Juan has fairly coarse-textured soils and the lowest soil pH and extractable phosphorus. Although the upper basins have parent material similar to that in Washington Creek, the lower areas above and surrounding the meadows are dominated by acidic volcanic tuffs, rhyolites, and breccias with lower base metal contents (Stewart and McKee 1977).

These results indicate that the physical and chemical soil characteristics of riparian areas exhibit high spatial variability and must be carefully interpreted when classifying ecosystems or evaluating ecosystem condition. The effects of differing soil water tables are often predictable for wetland soils (Mitsch and Gosselink 1993) and are fairly consistent among drainages in central Nevada. Soil water table depth significantly affects biotic processes in these ecosystems and, consequently, several soil properties, including bulk density, organic matter, total nitrogen, cation exchange capacity, and $\mathrm{pH}$, are highly responsive to depth to saturation. In addition, drainage basin geology has large influences on soil texture, $\mathrm{pH}$, extractable phosphorus and extractable potassium. This indicates that while depth to water table, soil descriptions, and soil properties such as organic matter and total nitrogen are reasonable characteristics for classifying meadow ecosystems, soil texture, $\mathrm{pH}$, extractable phosphorus and extractable potassium are not. Also, effective use of the soil characteristics examined here for evaluating soil "quality" or riparian ecosystem condition will require classifying ecosystems within fairly narrow ranges according to soil water table. It will also require developing expected ranges for the various soil characteristics based on drainage basin geology as has been done for agronomic soils. These soil characteristics could be incorporated into sampling schemes for collecting the vegetation and soils data necessary for ecosystem classifications. Before we can accurately assess how these soils respond to human-caused and natural disturbance on a landscape basis, we need to increase our understanding of their natural variability.

\section{Literature Cited}

Blake, G.R. and K.H. Hartge. 1986. Particle density. p. 377-382. In: A. Klute (ed.) Methods of soil analysis. Part 1. Physical and mineralogical methods. 2nd ed. Agron.and Soil Sci. Soc. Amer. Madison, Wis.

Brady, N. C. 1974. The nature and properties of soils. 8th ed. Macmillan, New York, NY.

Breckenridge, R. P., W. G. Kepner, and D. A. Mouat. 1995. A process for selecting indicators for monitoring conditions of rangeland health. Envir. Monitoring and Assess. 36: 45-60.
Bremner, J.M. and C.S. Mulvaney. 1982. Nitrogen-total. pp. 596-624. In: A.L. Page, R.H. Miller, and D.R. Keeney (eds.). Methods of Soil Analysis. Part 2. Chemical and Microbiological Properties. 2nd edition. Agron. Series No. 9. Amer. Soc. Agron., Inc., and Soil Sci. Soc. Amer., Madison, Wis.

Chambers, J.C. 1994. Maintaining and restoring riparian ecosystem integrity in Central Nevada: An interdisciplinary ecosystem management project. In: Diverse Values: Seeking Common Ground. Northwest Regional Symposium, Boise, Ida. December 8-9, 1994.

Doran, J. W. and T. B. Parkin. 1994. Defining and assessing soil quality. p. 3-22. In: Doran, J.W., Coleman, D. C., Bezdicek, D. F., and B. A. Stewart (eds). Defining soil quality for a sustainable environment. SSSA Special Publ. No. 35. Soil Sci. Soc. Amer. and Amer. Soc. Agron, Madison, Wis.

Doran, J. W. and T. B. Parkin. 1996. Quantitative indicators of soil quality: a minimum data set. p. 25-37. In: Doran, J. W., and A. J. Jones (eds). Methods of assessing soil quality. SSSA Special Publication No. 49. Soil Sci. Soc. Amer. and Amer. Soc. Agron, Madison, Wis.

Duchaufour, P. 1977. Pedology. Translated by T.R. Paton. George Allen and Unwin, London. 448 p.

Gee, G.W. and J.W. Bauder. 1982. Particle-size analysis. p. 383-412. In: A. Klute (ed.) Methods of Soil Analysis. Part 1. Physical and Mineralogical Methods. 2nd edition. Agronomy Series No. 9. Agron. Series No. 9. Amer. Soc. Agron., Inc., and Soil Sci. Soc. Amer., Madison, Wis.

Hansen, P. L. 1992. Classification and management of riparian-wetland shrub sites in Montana. p. 68-7. In: W. P. Clary, E. D. McArthur, D. Bedunah, and C. L. Wambolt (eds.) Proceedings-Symposium on ecology and management of riparian shrub communities. USDA Forest Serv., Intermountain Res. Sta., Ogden, Uta. Gen. Tech. Rep. INT-289.

Harris, R. F., D. L. Karlen, and D. J. Mulla. 1996. A conceptual framework for assessment and management of soil quality and health. p. 61-82. In: Doran, J. W., and A. J. Jones (eds). Methods of assessing soil quality. SSSA Special Publication No. 49. Soil Sci. Soc. Amer. and Amer. Soc. Agron, Madison, Wis.

Hess, G. W. and L. R. Bohman. 1996. Techniques for estimating streamflow at gaged sites and monthly streamflow duration characteristics at ungaged sites in central Nevada. US Geol. Surv., Carsen City, Nev. Open-File Rep. 96-559. 
Johnston, C.A., G. Pinay, C. Arens, and R.J. Naiman. 1995. Influence of soil properties on the geochemistry of a beaver meadow hydrosequence. Soil Sci. Soc. Amer. J. 59:1789-1799.

Kleinhample, F.J. and J.I. Ziony. 1985. Geology of Northern Nye County, Nevada. Nevada Bureau of Mines and Geology, Bull. 99A. Univ. Nevada, Reno. $172 \mathrm{p}$.

Klute, A. 1982. Water retention: laboratory methods. p. 635-662. In: A. Klute (ed.) Methods of Soil Analysis. Part 1. Physical and Mineralogical Methods. 2nd edition. Agron. Series No. 9. Amer. Soc. Agron. Inc., and Soil Sci. Soc. Amer., Madison, Wis.

Lindsay, W.L. 1979. Chemical equilibria in soils. John Wiley \& Sons, New York.

Malanson, G. P. 1993. Riparian landscapes. Cambridge Studies in Ecology. Cambridge University Press, Cambridge, Great Britain.

McLean, E.O. 1982. Soil pH and lime requirement. p. 199-224. In : A.L. Page, R.H. Miller, and D.R. Keeney (eds.). Methods of Soil Analysis. Part 2. Chemical and Microbiological Properties. 2nd edition. Agron. Series No. 9. Amer. Soc. Agron., Inc., and Soil Sci. Soc. Amer., Madison, Wis.
Miller, C.E., L.M. Turk, and H.D. Foth. 1965. Fundamentals of soil science. John Wiley and Sons. New York, N.Y. 491 p.

Mitsch, W. J. and J. G. Gosselink. 1993. Wetlands. 2nd edition. Van Nostrand Reinhold. London. 722 p.

Naiman, R.J., G. Pinay, C.A. Johnston, and J. Pastor. 1994. Beaver influences on the long-term biogeochemical characteristics of boreal forest drainage networks. Ecol. 75:905-921.

Olsen, S.R. and L.E. Sommers. 1982. Phosphorus. p. 403-430. In: A.L. Page, R.H. Miller, and D.R. Keeney (eds.). Methods of Soil Analysis. Part 2. Chemical and microbiological properties. 2nd edition. Agron. Series No. 9. Amer. Soc. Agron., Inc., and Soil Sci. Soc. Amer., Madison, Wis.

Schulte, E.E. 1988. Recommended soil organic matter tests. p. 29-31. In: W. Dahnke (ed.) Recommended Chemical Soil Test Procedures for the North Central Region. North Dakota Agr.. Exp. Sta. Bull. 499 (revised).

Soil Survey Staff. 1984. Procedures for collecting soil samples and methods of analysis for soil survey. Soil Survey Investig. Rep. no. 1. USDA-SCS. U.S. Gov. Print. Office, Washington, D.C.

Statistical Analysis System. 1990. SAS/STAT User's Guide. Version 6, Fourth Edition. Volume 1. SAS Institute, Inc. Cary, N.C.
Steel, R.G.D. and J.H. Torrie. 1980. Principles and procedures of statistics. 2nd ed. McGraw-Hill Book Company. New York, N.Y.

Stewart, J.H. and E.H. McKee. 1977. Geology and mineral deposits of Lander County, Nevada. Part I. Geology. Nevada Bureau of Mines and Geology. Bull. 88.

Storer, D.A. 1984. A simple high sample volume ashing procedure for determining soil organic matter. Comm. Soil Sci. Plant Anal. 15:759-772.

Thomas, G.W. 1982. Exchangeable cations. p. 159-166. In: A.L. Page, R.H. Miller, and D.R. Keeney (eds.). Methods of soil analysis. Part 2. Chemical and microbiological properties. 2nd edition. Agron. Series No. 9. Amer. Soc. Agron., Inc., and Soil Sci. Soc. Amer., Madison, Wis.

USDA Forest Service. 1996. Central Nevada riparian field guide. Intermountain Region. R6-ECOL-TP.

Weixelman, D.A., D.C. Zamudio, K.A. Zamudio, and R.J. Tausch. 1997. Classifying ecological types and evaluating site degradation. J. Range Manage. 50:315-321.

Wilson, A. D. and G. J. Tupper. 1982. Concepts and factors applicable to the measurement of range condition. J. Range Manage. 35:684-689.

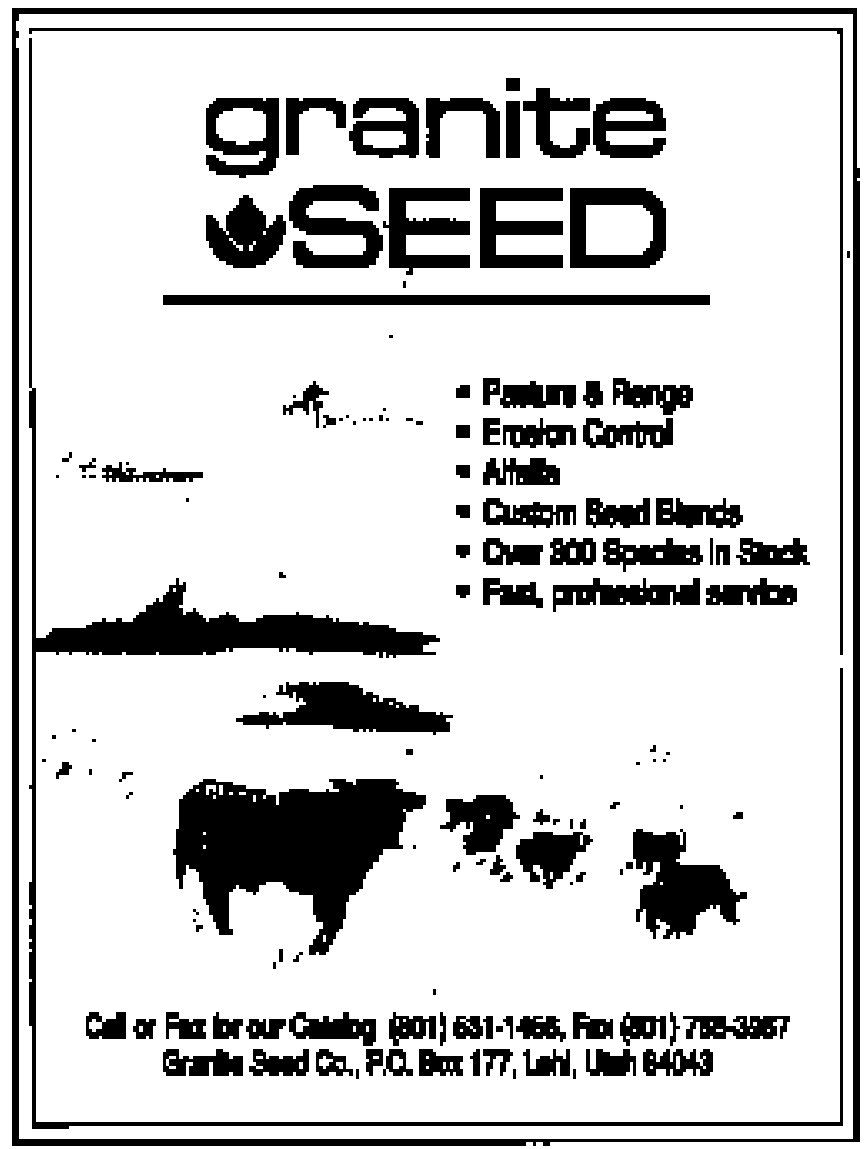

